\title{
Translation Challenges in the Translation of Ananse the Stomach Journalist
}

\author{
Dr. Marcel Kakpo, Dr. Patrice Akogbeto Maitre, Dr. Rissikatou Moustapha Babalola
}

\begin{abstract}
This article examines how translation can be done effectively and proposes some strategies drawing mainly on translation of written texts between English and French. Ananse the stomach journalist is the short story on which we focus to point out problems faced by translators while translating a text from one language into another. In addition to the translation interests that the short story bears, it reveals some realities of African countries such as corruption, illegality etc. It points out the behaviors of some African leaders who legislate good laws which are supposed to rule everybody as equal creature but which they classify to be executed by governed or poor people only. In a nutshell, it shows the hidden injustice which hinders African countries evolvement. This short story we translate from English into French helps to find out the different problems translators meet; Translating cultural elements can be a demanding task due to the fact that such elements have specific meanings in the culture and language in which they arise. Taking this fact into account, this study has investigated the strategies used in translating culture-bound elements in the English subtitles of Ananse the stomach journalist. The concluding part examines the issues emerging from the study, analyzes written texts between English and French.
\end{abstract}

Keywords: effective translation, translation strategies Anansé, Stomach journalist, Culture-bound terms.

\section{INTRODUCTION}

Today's world is more than ever before a world of communication. Communication is an important part of today's business world. When two or more people meet, they exchange ideas and experiences about their needs; they communicate to know the hope, will, advice, command of each other"s. Communication has thus become the key to a good relationship, business and other activities. In a nutshell, communication is central to most human activities in today"s competitive world and its success or failure depends upon the tools and the techniques used. Because of the multiplicity of languages, communication therefore poses a serious crosscultural problem, since it is quite impossible for an individual to master the entire world languages. How to communicate fairly with the whole world, despite this multiplicity? Translation practice came up to facilitate communication and mutual comprehension between people. Thus, great works of art and sacred books are translated from one language into another. Translation proves to be the real key to the globalization phenomenon without which, scientific or technological progress is not possible.

\subsection{Problem Statement}

Every speaker may pretend to be translator since they speak properly the source language as the target language, which may somewhat prove true, but the real problem arises when while translating, they think to provide just the TL equivalent which occurred to them. In 2011, at the occasion of the panafrican congress in Cameroun (Yaoundé). The francophone speaker said:.

«Jai tellement aimé mon premier enfant que je me demandais si je pouvais en aimer d"eautres. Ma femme devint enceinte du second enfant et elle fit une fausse couche »

He was translated as:

"l have so loved my first child that I wondered if 1 could love others. My wife became pregnant of the second child and she aborted it."

This translation set a great confusion in the target language listener understanding. In fact, the speaker spoke out against and banned abortion in his earlier words but the translation rather 
contradicted his position and make the listeners confused. Indeed "fausse couche", miscarriage in English are not the same as "abortion". Miscarriage is not an expected event. It is unhappy happening. Abortion, on the contrary is something planned and carried out. It is a choice. Therefore the listeners wondered if abortion is rather being campaigned for. Thus translation if mistaken may cause confusion and even serious damages. Japan would have not been bombed by the allies at the end of July 1945 if it had not been for the Japan word "mokusatsu" meaning "to consider" but mistaken for "to take no notice of". But translation should not be such an unreliable tool. In this perspective, Bell (1991: XVI) discussing a paper Halliday wrote in 1960 stressed the need to set up a model of translation based on linguistic concepts and made the following remarks: «In a rapidly changing world in which knowledge is expanding at an unprecedented rate information transfer is coming to depend more and more on efficient and effective translation.\|

\subsection{Purpose of Research}

Translation is often difficult or nearly impossible when translators are confronted with how to translate: proper names; figurative sentences; faithful and false friends; culture-bound terms; assessment is made of word for word translation "s limits betwixt the two languages. The purpose of this research work is then to investigate how efficient and effective translation can be achieved. In this vein strategies used to solve translation problems have been assessed with effort made to find out their strength and weaknesses. Ananse the stomach journalist has been translated accordingly based on a strategy which brings out meaning as wholly as possible and unambiguously from the source language texts (SLT) to the target language text (TLT).

\subsection{Research Questions}

A critical overview of the translation task and the functional areas has generated a number of research questions that will help to get to the heart of the problem.

1. What strategies are used in translations?

2. Are there strategies which help convey the meaning in every field?

3. Do the strategies bring out meaning wholly and clearly to the reader?

4. How to translate figurative sentences; culture-bound texts; proper or Character common names?

5. What is then lost/gained in text translation?

\subsection{Significance of Study}

1. The research will help translators to appreciate the problems involved in carrying meaning from one language into another.

2. The strategies recommended are adapted to suit the translation of other languages.

\subsection{Methodology}

Reading works by specialists of translation has allowed us to put up some questionnaires for professionals translators. Discussions are held with professional translators and interpreters, elderly speakers of French and English as well as scholars in the field of translation to investigate translation problems and possible solutions.

This article comprises four chapters. The introduction, the literature review and theoretical framework. Chapter three deals with the types of translation with a discussion on factors affecting translation. Chapter four deals with problem met while translating Anansé the stomach journalist into French with issues emerging from it.

\section{Definition And Purpose of Translation}

The online encyclopedia, Wikipedia defines translation as the communication of the meaning of a source-language text by means of an equivalent target language text. Ukoyen (2001:4) sides with the encyclopedia definition by saying that translation is the act of conveying ideas and information from one language to the other by writing; he then means that translation deals with the meaning of the source text into a target-text. This definition underlines the source language and the target 
language which imply two cultures, two morphologies, and two lexicons in translation process. Vinay and Darbelnet (1958:331) defines translation as une transposition d'une langue a vers une langue $B$ pour exprimer la même réalité. From this point of view they postulate that translation is obviously a wide ranging discipline as it bases on the knowledge of two linguistic structures, two lexis, and two morphologies but moreover as it bases on two different cultures, literature, histories and geographies. But Ladmiral (1979:9) postulates translation as all forms of interlinguistic meditations enabling to pass information between speakers of different languages. Nida and Taber (1974:5) acknowledge that globally, translating consists in reproducing in the receptor language the closest natural equivalent of the source-language message; first in terms of meaning and secondly in terms of style. Cartford (1965:20) defining translation as an act of communication that enables an author to pass a message on to a receiver, who does not speak the same language as him through a translator, emphasizes the notion of author and receiver. This means that every translation involves at least two languages the source language and the target language, or the speaker and the receiver .Therein, Robert de Retina (2007) stated that the main purpose of translation is to make easier to understand the message contained in the source text.

Dolet set out five principles in order of importance as follows to succeed translation task:

1. The translator must perfectly understand the sense and material of the original author, although he [sic] should feel free to clarify obscurities.

2. The translator should have a perfect knowledge of both SL and TL, so as not to lessen the majesty of the language.

3. The translator should avoid word-for-word renderings.

4. The translator should avoid Latinate and unusual forms.

5. The translator should assemble and liaise words eloquently to avoid clumsiness.

And, where Dolet has five „principles", Tytler (1797: 15) has three general „laws“e or „rules":

1. The translation should give a complete transcript of the ideas of the original work.

2. The style and manner of writing should be of the same character with that of the original.

The Institute of Linguistes (IoL) in the UK provides the following criteria for assessing the translations:

1. Accuracy: the correct transfer of information and evidence of complete comprehension;

2. The appropriate choice of vocabulary, idiom, terminology and register;

3. Cohesion, coherence and organization;

4. Accuracy in technical aspects of punctuation, etc.

For Jakobson, cross-linguistic differences centre around obligatory grammatical and lexical form: Languages differ essentially in what they must convey and not in what they may convey"e ( $p$. 116).

Examples of differences are easy to find. They occur at:

- The level of gender:

- The level of aspect:

- The level of semantic field:

For Nida, "the success of translation depends above all on achieving equivalent response". It is one of the four basic requirements of a translationwhich are (p. 164):

1. Making sense;

2. Conveying the spirit and manner of the original;

3. Having a natural and easy form of expression;

4. Producing a similar response. 


\section{The Complexity of Meaning}

De Saussure (1916) cited in Bell (1991:79) states the important place meaning occupies in the art of translation. He says meaning is "the kingpin of translation studies. Without understanding what the text to be translated means for the L2 users the translators will be hopelessly lost. This is why the translation scholar has to be a semanticist over and above everything else."

\section{Problemes of Translation}

Translating Ananse the Stomach Journalist, faces us with many problems such as: (1) Proper and character"s names translation, (2) culture-bound words translation (3), Weaknesses of word for word translation (4); translation of figure language (5); translation faithful and false friend (6) proverbs translation; (7) the translation of postpositional phrases.

\subsection{Proper and Character's Names}

When confronted with Proper and Character's Names in translation, the first question translators ask is: "should I translate them or transfer? If 1 should translate, are all of them translatable?" For Newmark (1988), people's first and surnames are transferred preserving their nationality, assuming that they have no connotations in the text. The exception to this rule is the names of Saints and Monarchs which yet, are sometimes translatable. The names of Popes are translated, nevertheless some French kings like (ST Louis, Francois). In English, character"es names are written with capital letter in creative writing whereas in French only proper names and characters are written with capital letter at the beginning. - Anansell being a character proper name, we simply transfer it, especially as there is no pure equivalent for it in French. Names are specific Identity related to an Individual or another and since they identify, they cannot be changed abruptly, for an individual cannot change his identity from an ethnic group to another. "Paul Goudou" in Benin remains Paul Goudou in Togo. Nevertheless a meaningful cultural name can be translated only when its linguistic understanding is necessary for a better comprehension of the text. But regarding the names quoted from "Ananse the stomach journalist" they are most, common nouns such as:

- "Dog" meaning "Chien" in French but Marcus cannot be translated so it can give "ChienMarcus" we realize that there are not cultural names, nor proper names but common names sotranslatable.

Their equivalents in French are as follows:

- The second character name is "Giant Dwarf" as it is a common name, having its equivalent in French we have:

- "Giant\| that we translate as "Grand\| and-Dwarf" that we translate as "Nain" so by deduction-Giant Dwarf"s translation gives "grand Nain"

- The name we have here is "King Giant Dwarf" that we translate as "Roi Grand Nain"

- Another word is "White Sea" that we translate as "Mer Blanche". The two words have their equivalents in the target language. For Newmark (1988), we would not translate "white sea" for, names of objects as proper names consist of trademarks, brand or proprietaries. So they are normally transferred often coupled with a classifier if the name is not likely to be known to the Target Language readership but here the target language does not affect the meaning.

- Another name is "Dark Smoke" that we translate as "Fumée Noir" from dictionary

- Here we have as a character's names "Red Baby Lion" that we translate as follows : First to render "Baby Lion" in word for word translation, it gives "bébé lion" which semantically in French has as equivalent "Lionceau" so the translation of "Red Baby Lion" reverts to be "Lionceau Rouge"

- Other character"s name is "Dog Marcus" this is complex by the fact that it is a compound name with one word translatable and the other untranslatable. It goes as follows: "Dog" is translated as "Chien" whereas "Marcus" is untranslatable so the target version must be compound as follows "Chien Marcus" 
- Another name at issue is "Red Ant Square" that we translate as "Place des fourmis rouges"

- Another one is "Brown Tortoise" that we translate as "Tortue Brune"

- The last one in this rubric is "Cola Baby" That we translate as "Cola Bébé"

\subsection{Problem of Faithful and False Friends in Translation}

Delisle (1981), in Gerding Salas article, described translation as "an arduous job that mortifies you,puts you in a state of despair" (2003). This problem stems mostly from nonequivalence between the source text (ST) and the target text (TT) and language transfer. False friends, According to Mounin et al, the term, faux amis ' was first used by Koessler and Derocquigny (1974). He said that 'faux amis" "désigne les mots partiellement ou totalement différents" (Mounin et al, 1974 : 139). In a similar vein, Chuquet and Paillard defined them as "mots qui sont, [...] proches par la forme mais partiellement ou totalement différent par le sens" (1989: 224). This section aims at casting light on the significant problems that false friends constitute mainly in translation, so that it might provide translators with some insights to handle the difficulties and avoid errors they give rise to. As every French word or alike encountered in English for instance while translating, are not faithful friends, translator should see to the fitness, and correctness of words and expression in use to render more appropriate the Target Text.

- Let"s consider for example the words "cause" met in Ananse the stomach journalist, which has as meaning in French: causer, provoquer, occasionner, susciter. The words which can help convey naturally its meaning is "semer"

- The second word which is false friend in the translation of this excerpt is "administration" that word in French has as equivalent: Administration, government, Its suitable meaning as used in Ananse the stomach journalist is"governance"

- Third false friend we encountered is "report". A bad translator may render it as "reporter" since the root is the same, but it would jeopardize the understanding to the target text reader. The equivalence provided by dictionnaries are:" rendre compte, rapporter, signaler, rédiger un rapport. But as used in Ananse the stomach journalist the most appropriate equivalence is "rendre compte".

- The next word is "Distract" The equivalent dictionaries provide are: distraire, deconcentrer, derranger but here it is used as prepositional phrase so, the translator should translate that verb as phrasal verb in order to render the equivalent of the prepositional phrase instead of the verb equivalent. Therefore the phrase equivalent gives "empêcher"

- other false friend is "corporation" translated here as "sociéte" "syndicat" "compagniell

- Another phrase which poses meaning problem is "extra money", It"s word for word translation gives "extra somme" which doesn"t convey coherent meaning. The convenient meaning 1 find is "revenue suplementaire"

- Another false friend is "Action" Which also exists in French with other equivalent .The equivalent 1 find suitable to it as used in Ananse the stomach journalist is "actes"

- "Disgrace" The equivalent dictionaries provide are: disgrace, honte, deshonneur, defaveur but the meaning which suits to it, as used in Ananse the stomach journalist is "humilier"

\subsection{Culture-Bound Terms}

For Newmark (1988:94) "culture is the way of life and its manifestations that are peculiar to community that uses a particular language as its means of expression\| According to Hatim and Mason (1990, pp. 223-4) "it is certainly true that in recent years, translator has increasingly come to be seen as a cultural mediator rather than a mere linguistic broker. It is also true that, in any form of translation, translators tend to apply a general strategy that will favor either an SLoriented approach, or a TL-oriented approach."Newmark (1988, p.78) maintains that translation problems caused by culture-specific words arise due to the fact that they are intrinsically and uniquely bound to the culture concerned and, therefore, are related to the "context of a cultural tradition" There are many ways to categorize culture-specific items, for instance Newmark (1988) points out five areas that cultural items may come from: 
(1) Ecology (flora, fauna, winds, etc),

(2) Material culture (artifacts food clothes houses and towns, transport),

(3) Social culture (work and leisure),

(4) Organizations, customs A, ideas (political, social, legal, religion or artistic),

(5) Gestures and habits.

\subsection{Translation Strategies for Cultural Specific Items}

Vinay and Darbelnet quoted by Munday, (2001, pp. 56-60) in their cultural theory of translation believe that there could be different translation procedures for rendering a word from SL to TL: 1) Borrowing; 2) Calque (loan shift) ;3) Literal Translation;4) Transposition (Shift); 5) Modulation; 6) Equivalence Journal of Academic and Applied Studies; 7) Adaptation. In Mona Baker's (1998) theory, provided seven different procedures for culture-bound elements translation: 1) A more general word (subordinate) ;2) A more natural/less expressive word ;3) Cultural substitution; 4) Using a loan word or a loan word plus explanation ;5) Paraphrase using unrelated words ;6) Omission 7) Illustration. In Newmark's (1988) theory there are 17 strategies for translation of culturespecific items. We simply apply his fisrt and seventh methods to translate the culture bound words "fufu" and -kenkey"

\subsection{Weaknesses of Word for Word Translation}

A Translator must analyze first the ST's word; phrase or sentence to render rather sense for sense so as to be sure to have provided faithfully the equivalent of the ST as proposed St Jerome (CE/1997:25). The following board contains some examples

\begin{tabular}{|l|l|l|}
\hline Source language text & Word for word Translation & Sense for sense translation \\
\hline Let the matter die here" & Fait l"affaire mourir ici & Laisse tomber l"affaire ici \\
Otherwise oil will drip into fire & Sinon l"huile goutera dans le feu & Sinon ca va s"aggraver \\
On the day when & Sur le jour quand & le jour où \\
Still water & Immobile eau & eau (calme) Stagnante \\
To give his address & donner son addresse/allocution & faire son discours \\
all the same" & Tout le même & tout de même \\
Your highness & Votre altesse & Votre majesté
\end{tabular}

\subsection{Problem of Proverb Translation}

Palmer (1976: 21) states that: "The words of a language often reflect not so much the reality of the word but the interests of the people who speak it."Then, the sentence's meaning in this context is beyond the words it is composed of. The same principle worths for the translation of the figure of style. Translator must aim at the communicative intention of the source text writer.

When 1 consider this sentence from the text we have translated

"We must all serve as ears and eyes for the smooth running of our cherished kingdom"

Word for word translation gives into French:

$$
\begin{aligned}
& \text { Nous devons tous servir comme des oreilles et des yeux pour une gestion paisible de } \\
& \text { notre chéri royaume }
\end{aligned}
$$

The intention of the speaker to use that comparison is to invite one and the other to fair service rendering for a good running of their kingdom so the TT may vary provided it conveys the real message

\subsection{Translating Figure of Speech}

Some figure of speech and metaphoric expressions are not stylistically translated. For example, the figure of style:

\section{"Oil will drip in fire" (literally, translated as}

"L 'huile coulera dans le feu" is like an image which convey a message like it will be worsened "ca vas'empirer" 


\section{Conclusion}

This section includes the researcher's main observations and the implications of the study. The translation challenges encountered and the different method that can best apply to solve problems it brings about. It is intended to facilitate the reader to understand the scope of the problems that were solved. This research work aimed at emphasizing most of the problems translators have while translating. It started with a background survey on the importance of communication in every area of today's world. Communication being a key to good relationship between companies, workers, entrepreneurs, scientific, it becomes irresistible to act for a good communication, planetary village as the world has become. Developing communication is to foresee a means by which what is said in one language can be understood to every other languages speaker to whom the messages conveyed are useful, or addressed to. Many Authors have underlined what translation consists of and what its aims are. Nevertheless some dimensions of translation still escape to machinery especially when translators have to deal with proper nouns or characters name translating, culture bound texts translation, problems of false friend's translation, problems of figures of style translation, problems of proverbs translations.

From the discussion of the text and its translation, it is noted that to translate effectively the translator should not be so much carried away in his enthusiasm to translate by the syntactic-semantic organization in a particular language only. He must apply himself to the real situation that the writer is expressing in the text. This is because translation is not restricted to words and grammar. Social context; jargon and culture play an important part.

Most of the respondents recognize to meet problems related to proper, or common noun translation. From their answers we conclude that common name used as character in text can be translated when it is translatable but transferred when it doesn "et have its equivalent in a target language. Proper names as for them are transferred. In addition; care must be taken by the translator of poems and culturally loaded texts. From the respondents with respect to the translation of culture-bound terms, recommendations are made to future translators to resort to the source language culture to have the fair equivalent of the source language term.

The same process is suggested to the professional translators when confronted with technical or legal words and expression. They must go to the servant of those fields to inquire about the possible implications of the expressions or words of which fair equivalents are difficult to find. intention of the source language writer.

Some respondent suggested that proverbs must be rendered by their corresponding of the target language. Translator must see to each expression or word to translate with the communicative intention of the source language writer.

\section{REFERENCES}

\section{Corpus}

[1] Antobam, R. (n.d.). Ananse the Stomach Journalist. Edited by Koomson, E.

Books

[2] Bassnett, S. (1980/1991). Translation Studies. London and New York: Routledge.

[3] Brislin, R. W. (1976). Translation: Application and Research. New York: Gardner Press Inc.

[4] Bell, R.T. (1991). Translation and Translating. London: Longman.

[5] Catford, J.C. (1965). A Linguistic Theory of Translation: An Essay in Applied Linguistics. Oxford:

[6] Oxford University Press.

[7] Delisle, J. (1981). L'enseignement de l'interprétation et de la traduction : de la théorie à la

[8] pédagogie. Ottawa : Editions de l'Université d'Ottawa.

[9] Delisle, J. (1982). L'analyse du discours comme méthode de traduction : initiation - la traduction

[10] française de textes pragmatiques anglais : Théorie et pratique, Ottawa:Editions de l'Université

[11] d'Ottawa.

[12] Duthie, A.S. (1985). Bible Translations and How to Choose Between them. Exeter, Devon:

[13] Paternoster Press.

[14] Dzobo, N.K.(1997). African Proverbs Vol. II. Accra: Bureau of Ghana Languages. 
[15] Firth, J.R.(1964). Papers in Linguistics (1993-1951). Oxford: Oxford University Press.

[16] Gentzler, E C. (1993). Contemporary Translation Theories. London: Routledge.

[17] Greenberg, J.H (1966). The Languages of Africa. Bloomington: Indiana University Press.

[18] Gumperz, J.J. (1971). Language in Social Groups. Stanford: Stanford University Press.

[19] Gutt, E.-A. (1993). Translation and Relevance. Masachusetts: Blackwell.

[20] Hatim, B., Mason, I. (1990). Discourse and the Translator. New York: Longman.

[21] Hatim, B. \& Mason, I. (1997). The Translator as Communicator. London: Routledge.

[22] Hatim, B. (1997/2000). Communication across cultures. Translation theory and contrastive text linguistics. Exeter: University of Exeter Press.

[23] Hatim, B. (2001). Teaching and Researching Translation. Harlow: Longman.

[24] Hatim, B. \& Munday, J. (2004). Translation. An advanced resource book, London: Routledge.

[25] Holmes, J. S. et al. (ed.) (1970). The Nature of Translation: Essays in the Theory and Practice of Literary Translation. The Hague: Mouton.

[26] Holmes, J. S. et al. (eds.) (1978). Literature and Translation: New Perspectives in Literary Studies. Leuven: Acco

[27] Kelly, L. G. (1979). The True Interpreter: A History of Translation Theory and Practice in the West. Oxford: Blackwell..

[28] Kodzo-Vordoagu, J. G. (1994). Antolo Hogbetsotso Festival. Accra: Domak.

[29] Koller, W. (1979a). Einfuhrung in die ïbersetzungswissenschaft. Heidelberg-Wiesbaden: Quelle und Meyer.

[30] Koller, W. (1979b). „Equivalence in translation theory“ translated by A. Chesterman (ed) (1989). Paris: Larousse.

[31] Kramsch, C. (1998). Language and culture. Oxford: Oxford University Press.

[32] Larose, R. (1989). Théories contemporaines de la traduction (2nd ed). Québec: Presses de l'e Université du Québec. nd

[33] Larsen, M. (1984). Meaning-based translation: A guide to cross-language equivalence (2 ed). London: University Press of America.

[34] Lefevere, A. (1977). Translating Literature: the German Tradition from Luther to Rosenzweig. Assen: Van Gorcum.

[35] Lefevere, A. (1992a). Translating Literature: Practice and Theory in a Comparative Literature Context. New York: Modern Language Association of America.

[36] Lefevere, A. ed. (1992b). Translation $\div$ History, Culture: a Sourcebook. London: Routledge.

[37] Lefevere, A. (1992c). Translation, Rewriting \& the Manipulation of Literary Fame. London and New York: Routledge.

[38] Leech, G. (1981). Semantics, the Study of Meaning. Harmondworth: Penguin.

[39] Leppihalme, R. (1997). Culture bumps. Clevedon: Multilingual Matters.

[40] Levy, J. (1969). Die literarische Übersetzung: TheorieeinerKunstgattung. Frankfurt am Main: Athenäum.

[41] Lord, C. (1993). Historical Change in Serial Verb Constructions. Amsterdam: John Benjamins Publishing Company.

[42] Lyons, J. (1981). Language and Linguistics: an Introduction. Cambridge: Cambridge University Press.

[43] McGuire, S.B. (1980). Translation Studies. New York: Methuen.

[44] Motte, S.A. (1968). Mia Denyigba. Accra: Bureau of ghanna Languages.

[45] Mounin, G. (1955). Les belles infidèles. Paris : Cahiers du Sud.

[46] Mounin, G. (1963). Les problèmes théoriques de la traduction. Paris : Gallimard.

[47] Mounin, G. (1976). Linguistique et traduction. Brussels : Dessartet \& Mardaga.

[48] Munday, J. (2001). Introducing Translation Studies. Theories and Applications. London: Routledge.

[49] Newmark, P. (1981). Approaches to translation. New York: Pergamon.

[50] Newmark, P. (1988). A Textbook of translation. London: Prentice-Hall.

[51] Newmark, P. (1995). Paragraphs on translation. Adelaide: Multilingual Matters.

[52] Nida, E. (1964a). Toward a science of Translating. Leiden: E.J. Brill.

[53] Nida, E.A. \& Taber, C. R. (1969). The theory and practice of translation. Leiden: Brill.

[54] O'Connor, J. \& Seymou , J. (1990). An introduction to neurolinguistic programming. London: Mondela 
[55] Palmer, F. R. (1976). Semantics. Cambridge: Cambridge University Press.

[56] Robinson, D. (1997a). Western Translation Theory from Herodotus to Nietzsche. Manchester: St. Jerome Publishing.

[57] Robinson, D. (1997b). What is translation? : centrifugal theories, critical interventions. Kent, Ohio: Kent State University Press.

[58] Robinson, D. (1997c). Translation and Empire: Postcolonial Theories Explained. Manchester: St. Jerome Press.

[59] Robinson, D. (1991). The Translator's Turn. London: The John Hopkins University Press.

[60] Robinson, D. (2003). Becoming a translator: an introduction to the theory and practice of translation. London: Routledge.

[61] Shakespeare, W. (1965). Macbeth, London: Longman

[62] Snell-Hornby, M. (1988). Translation studies: An integrated approach. Amsterdam: John Benjamins.

[63] Van Hoof, H. (1991). Histoire de la traduction en Occident : France, Grande-Bretagne, Allemagne, Russie, Pays-Bas. Paris : Duculot.

[64] Van Leuven-Zwart, K. M. \&Naaijkens, T. (eds.) (1991). Translation Studies: State of the Art. Amsterdam: Rodopi.

[65] Venuti, L. (ed.) (1992). Rethinking Translation: Discourse, Subjectivity, and Ideology. London: Routledge.

[66] Venuti, L. (1995). The Translator's Invisibility: A History of Translation. London: Routledge

[67] Venuti, L. (1998). The Scandals of Translation: Towards an Ethics of Difference. New York: Routledge.

[68] Venuti, L. (2000). The Translation Studies Reader. London: Routledge.

[69] Wills, W. (1977). Übersetzungswissenschaft. Probleme und Methoden. (trans. The Science of Translation. Problems and methods). Tübingen: Günther Narr

[70] Wills, W. (1996). Knowledge and Skills in Translation Behavior. Amsterdam: John Benjamins.

[71] Venuti, L. (1995). The translator's invisibility: A history of translation. NewYork: Routledge.

[72] Venuti, L. (Ed) (2004). The translation studies reader. New York: Routledge.

[73] Van Valin, R.D. and LaPolla, R.J. (1997: 82). Syntax: Structure, Meaning, and Function. Cambridge: Cambridge University Press

[74] Wittgenstein, L. (1958). The Blue and Brown Books. Oxford: Blackwell.

III- Articles

[75] Anuszkiewicz-Misiaczek, M. (2005). "Strategies and methods in dealing with culture specific expressions on the basis of Polish-English translations of certain administrative andinstitutional terms". In Theory and Practice in English Studies, vol. 3, (Pp243-248).

[76] Biridilli, M-H. (1990). "National Languages" in the Courier No. 119 January-February 1990 (Pp.44- 45).

[77] Calfrod, J.C. (1994). "Translation Overview", In Asher, E. and Simpson, T. (Ed) The Encyclopedia of language and Linguistics, Oxford: Pergamon Press. Pp38-4.7

[78] Duthie, A.S.(1996a). "Translations of the bible and other Books: Comparing the Assessment Criteria" In Legon Journal Humanities Vol.IX 1996(ed. Dzamenshie).

[79] Dzameshie, A. (1997). "The Use of In group Linguistic Choices as Identification strategy of Persuasion in Christian Sermonic Discourse”. In Legon Journal of Humanities Vol. X 1997.pp. 127-148

[80] Hymes D.(1972). “On Communicative Competence”: In J.B. Pride and J. Holmes (Eds) Sociolinguistics. Harmondsworth: Penguin pp. 269-93.

[81] Holmes, J. S. (1988). "Translated!" in Papers on Literary Translation and Translation Studies (Coll.2). Amsterdam: van Rodopi.

[82] Jakobson, R. (1959/2000). „On linguistic aspects of translation ${ }^{e e}$, in L. Venuti (ed.) (2000) The translator's invisibility. A history of translation. London and New-York: Routledge (pp. 113-18).

[83] Kolers, P. A. (1973). “Translation and Bilingualism” in Communication, Language and Meaning, George A. Miller (ed.) pp123-157.

[84] Kroeber, A. L., \& Kluchohn, C. (1952). "Cultures: A critical review of concepts and definitions", in Peanbody Museum Papers, 47 (1), pp29-46.

[85] Levy, J. (1967). "Translation as a Decision Process", in To Honor Roman Jakobson, 3 vols, The Hague: Mouton, 2, pp1171-1182.

[86] Malinowski, B. (1923). "The Problem of Meaning in Primitive Languages" in Supplement to C.K. Ogden and I.A. Richards. The Meaning of Meaning. London: Kegan Paul. pp 296-336. 
[87] Nida E. (1964b/2000). „Principles of Correspondence ${ }^{e e}$, in L. Venuti (ed.), Translation and Translators. London: Routledge. pp. 126-40.

[88] Plotkin, H.(2001). "Some Elements of a Science of Culture". In Whitehouse, H. (ed.), The Debated Mind. Evolutionary Psychology versus Ethnography. Oxford, New York: Berg. Pp 91-109.

[89] Salehi, M. (2012)."Reflections on Culture, Language and Translation". In Journal of Academic and Applied Studies, 2(5), pp27-41.

[90] Torop, P. (2009). "Translation and Cultural Equivalence: A Study of Translation Losses in Arabic Literary Texts" in Journal of Language \& Translation 2(5), pp12-26.

[91] Vinay, J. \& Darbelnet, J (1958/1997). “A comparative stylistics of French and English: A methodology for translationll. In Munday, J. (2001) Introducing Translation Studies: Theories and Application. New York: Routledge.

\section{IV- Websites}

[92] Pedersen, J. (2005). "How is culture rendered in subtitles?" In MuTra Conference Proceedings. Available online at www.euroconferences.info/proceedings/2005_Proceedings/MuTra_2005. [Retrieved 7 November 2009]

[93] Wikipedia Online Encyclopedia. „Translation ${ }^{e e}$ available at. https//en.m.wikipedia.org/wiki/ translateon.html [Accessed on January 3, 2016]

\section{V- Encyclopedias and Dictionaries}

[94] Crystal, D. (1987). The Cambridge Encylopedia of language, Cambridge: Cambridge University Press.

\section{VI-Dissertations}

[95] Akpaca, S. (2008) etude linguistique des problems de traduction de - the life and times of an African trade unionist unpublished PhD Thesis. Université Lumiere Lyon 2 centre de recherché en terminologie et traduction

[96] Hala, L. (2011) la dimension culturelle dans la traduction audio visuelle. Cas du sous-titrage dans le film "Mascardes » de Lyses Salem. Memoire en vue deun Magistere en Traduction. Université MentouriConstantine, Faculte des lettrres et des langues ; Ecole doctorale de Traduction.

[97] Moustapha, R. (2013) Film Translation in Benin Republic: Problems and prospects, unpublished thesis, Ecole Doctorale FLASH UAC

[98] NGARAMBE, T. (2013) Translatability of customary laws: the case of Rwanda_s GACACA unpublished $\mathrm{PhD}$ thesis. National university of Rwanda. Department of Modern Languages

[99] Woodham, K. (2007) Translating Linguistic Innovation in Francophone African Novels, published $\mathrm{PhD}$ thesis University of Nottinghan.

\section{AUTHORS' BIOGRAPHY}

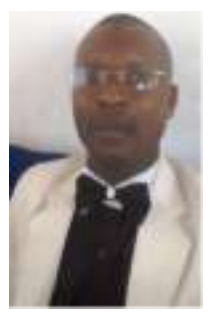

Dr Marcel Kakpo, Holding a doctorate degree in 2016, in Applied linguistics to Text Translation. Certified and sworn conference interpreter and translator

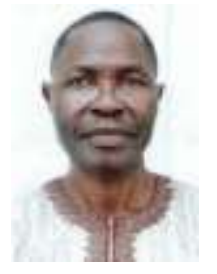

Dr. Patrice Akogbeto Maitre

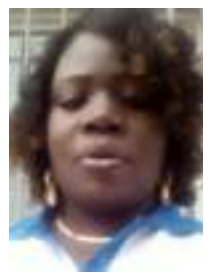

Dr. Rissikatou Moustapha Babalola,

Assistant Lecturer 